\title{
ЗУПИНЕННЯ ПРОВАДЖЕННЯ: ПРОБЛЕМИ ЗАКОНОДАВЧОГО РЕГУЛЮВАННЯ ТА СУДОВОї ПРАКТИКИ
}

\author{
УГРИНОВСЬКА Оксана Іванівна - кандидат юридичних наук, доцент \\ кафедри цивільного права та процесу Львівського національного університету \\ імені Івана Франка. \\ СЕМКО Юлія Володимирівна - магістрантка юридичного факультету \\ Львівського національного університету імені Івана Франка, спеціалізація \\ "HotapiaT".
}

DOI:10.32782/EP.2020.1.22

УДК 347.9

В статье исследуются основания обязательного приостановление производства по делу, практика применения судами статьи 251 Гражданского Процессуального кодекса Украины. Определяется важность этого института как процессуальной гарантии обеспечения прав и свобод участников процесса, в то же время нередко приостановление производства используются недобросовестнълми лицами для затягивания рассмотрения дела судом, последствием являются нарушения принципа разумности сроков рассмотрения дела судом и свидетельствует о злоупотреблении процессуальными правами. Для недопущения этих негативных явлений бъли направленъ внесеннъе в 2017 году изменения в Гражданский Прощессуальный кодекс Украинъ.

Особое внимание уделяется порядку привлечения прочессуального правопреемника прекращенного юридического лища, дается определение понятия «урегулирование спора с участием судъи», в статье содержатся ссълки на позиции Верховного суда, высвечиваются основные проблемъ, с которьми сталкиваются судьи, применяя исследуемвие в статье правовые нормы. Авторами предлагаются пути совершенствования норм о процессуальном правопреемстве и оснований обязательного приостановление производства судом.

Ключевъе слова: приостановление производства, прочессуальное правопреемство, Антитеррористическая операчия, Операиця обгединеннъх сил, урегулирование спора с участием судьи, преюдичия.

\section{Вступ}

15 грудня 2017 року набрали чинності зміни до процесуального законодавства (Закон № 2147-VIII) згідно з якими було змінено Цивільний процесуальний кодекс України (далі - ЦПК України), зокрема нововведення торкнулись інституту зупинення провадження у справі [5]. Зупинення провадження у справі - це тимчасове припинення судом вчинення процесуальних дій під час судового розгляду із визначених у законі об'єктивних підстав, які перешкоджають подальшому розгляду справи (Постанова Касаційного цивільного суду 23 січня 2019 року справа№ 462/3593/17).

Після грудня 2017 року юристи-практики зіштовхнулися 3 практичними проблемами втілення у життя прописаних статтею 251 ЦПК України норм про обов'язкове зупинення провадження [4]. Важко сказати, що внесені зміни призвели до однозначного удосконалення законодавчої регламентації досліджуваного інституту, проте прослідковуються суттєві покращення. Орієнтиром у хитросплетінні законодавчих конструкцій досі залишається судова практика.

Метою статті $є$ окреслення загальних проблем застосування обов'язкових підстав зупинення провадження судами, аналіз дій суду при застосуванні підстав, передбачених статтею 251 ЦПК України, визначення моменту припинення юридичної особи, що 6 підставою для залучення правонаступника, а також надання практичних рекомендацій 


\section{Цивільне, підприсмницьке, господарське та трудове право}

щодо вдосконалення нормативно-правового регулювання зупинення провадження у справі.

\section{ВикАад основного матеріалу}

Питанню зупинення провадження присвячено статті 251-254 Глави 8 нової редакції ЦПК України. Законодавцем було внесено якісні та кількісні зміни до визначення підстав та регулювання процедури зупинення провадження судом. 3 оновленого ЦПК України (а також Господарського процесуального кодексу України) виключено можливість зупинення провадження у зв'язку із злиттям, приєднанням, поділом, перетворенням юридичної особи, яка була стороною у справі, водночас, п. 1 ч. 2 статті 251 ЦПК України передбачає як обов'язкову підставу для зупинення провадження смерть або оголошення фізичної особи померлою, яка була стороною у справі, якщо спірні правовідносини допускають правонаступництво [1]. Натомість у п. 1. ч. 1 ст. 236 Кодексу адміністративного судочинства України злиття, приєднання, поділ, перетворення юридичної особи, яка була стороною у справі, якщо спірні правовідносини допускають правонаступництво, є однією з підстав для зупинення провадження за ухвалою суду - до встановлення правонаступника [2].

Реорганізація юридичної особи та смерть фізичної особи як юридичні факти, з наявністю яких пов'язують виникнення прав та обов'язків у правонаступника мають наступні відмінності. По-перше, смерть - це невідворотна подія, а реорганізація юридичної особи - це визначені нормами матеріального права дії комісії з реорганізації, спрямовані на припинення юридичної особи-правопопередника та передачу майна, прав та обов'язків правонаступнику. По-друге, оформлення спадкових прав спадкоємців фізичної особи можливе після спливу шести місяців 3 часу відкриття спадщини, до цього моменту ніхто не може бути уповноважений на ведення справ у суді від імені померлої особи, процес припинення юридичної особи $є$ тривалим, до внесення відповідних відомостей у Єдиний державний реєстр юридичних осіб, фізичних осіб - підприємців та громадських формувань, представництво іiі інтересів у суді здійснюють компетентні особи. Виключення юридичної особи-правопопередника 3 реєстру та передача прав та обов'язків правонаступнику збігаються у часі.

Стаття 104 Цивільного кодексу України (далі - ЦК України) встановлює, що юридична особа припиняється в результаті реорганізації (злиття, приєднання, поділу, перетворення) або ліквідації. У разі реорганізації юридичних осіб майно, права та обов'язки переходять до правонаступників. Юридична особа $є$ такою, що припинилася, $з$ дня внесення до єдиного державного реєстру запису про іï припинення [3]. Статтею 55 ЦПК України регламентовано порядок залучення до справи правонаступника юридичної особи, яка є стороною у справі або третьою особою у випадку, якщо спірні правовідносини допускають правонаступництво. Зауважимо, що ця норма підлягає застосуванню виключно, якщо юридична особа була реорганізована, оскільки ліквідація передбачає остаточне припинення iї існування як учасника цивільних (процесуальних) правовідносин без передачі прав та обов'язків правонаступникам, що тягне за собою закриття провадження у справі.

Варто зупинитись на процесуальних особливостях (відмінностях) правового статусу та дій суду, які вчиняються стосовно юридичної особи, яка перебуває у стані реорганізації та юридичної особи, процес припинення якої завершився.

Отже, згідно з ч. ч. 3- 4 статті 105 ЦК України, учасники юридичної особи, суд або орган, що прийняв рішення про припинення юридичної особи, призначають комісію з припинення юридичної особи (комісію з реорганізащиї) голову комісї та встановлюють порядок і строк заявлення кредиторами своїх вимог до юридичної особи, що припиняється. Виконання функцій комісії з припинення юридичної особи (комісії з реорганізації) може бути покладено на орган управління юридичної особи. Комісія з реорганізації, іiї член представляють іï у відносинах з третіми особами та виступають у суді від імені юридичної особи, яка припиняється. В даному випадку дії цих осіб по представництву юридичної особи тотожні представництву керівника, члена виконавчого органу, іншої особи, уповноваженої діяти від імені юридичної особи відповід- 
но до закону, статуту, положення, трудового договору (контракту) - (самопредставництво юридичної особи). Учасники юридичної особи, суд або орган, що прийняв рішення про припинення юридичної особи, зобов'язані протягом трьох робочих днів з дати прийняття рішення письмово повідомити орган, що здійснює державну реєстрацію.

Доречно навести позицію Касаційного цивільного суду від 18 вересня 2019 року у справі № 220/310/18 про момент припинення юридичної особи.

У лютому 2018 року ОСОБА_1 звернувся до суду з позовом до публічного акціонерного товариства «Українська залізниця» (далі ПАТ «Українська залізниця») про стягнення заборгованості по заробітній платі та середнього заробітку за час затримки розрахунку при звільненні.

Заочним рішенням Красноармійського міськрайонного суду Донецької області від 18 жовтня 2018 року у задоволені позову ОСОБА_1 відмовлено. Заочне рішення суду першої інстанції мотивоване тим, що належним відповідачем за вимогами ОСОБА_1 є ДП «Донецька залізниця», а не ПАТ «У ниця», оскільки ДП «Донецька залізниця» не ліквідовано, а ПАТ «Укрзалізниця» не стало остаточним правонаступником майна, прав i обов язків ДП «Донецька залізниця».

Постановою Донецького апеляційного суду від 21 лютого 2019 року апеляційну скаргу ОСОБА_1 рішення Красноармійського міськрайонного суду Донецької області від 18 жовтня 2018 року скасовано. Постанова апеляційного суду мотивована тим, що ДП «Донецька залізниця» реорганізовано шляхом злиття з ПАТ «Українська залізниця» та $\mathbf{E}$ регіональною філією даного товариства, тобто ПАТ «Українська залізниця» $є$ належним відповідачем та має сплатити заборгованість по заробітній платі ОСОБА_1 3 лютого 2016 року по квітень 2017 року.

Верховний суд надав наступні висновки: “Згідно з положеннями статті 107 ЦК України, якою закріплено порядок припинення юридичної особи шляхом злиття, приєднання, поділу та перетворення, після закінчення строку для пред явлення вимог кредиторами та задоволення чи відхилення цих вимог комісія з припинення юридичної особи скла- дає передавальний акт (у разі злиття, приєднання або перетворення) або розподільчий баланс (у разі поділу). Передавальний акт та розподільчий баланс затверджуються учасниками юридичної особи або органом, який прийняв рішення про iї припинення, крім випадків, встановлених законом. Порушення положень частин другої та третьої цієї статті $€$ підставою для відмови у внесенні до єдиного державного реєстру запису про припинення юридичної особи та державній реєстрації створюваних юридичних осіб - правонаступників.

При цьому, згідно зі статтею 104 ЦК України юридична особа припиняється в результаті передання всього свого майна, прав та обов язків іншим юридичним особам - правонаступникам (злиття, приєднання, поділу, перетворення) або в результаті ліквідації. Юридична особа є такою, що припинилася, 3 дня внесення до єдиного державного реєстру запису про її припинення.

Моментом переходу прав до правонаступника юридичної особи вважається дата внесення відповідного запису до Єдиного державного реєстру юридичних осіб та фізичних осіб підприємців у порядку, передбаченому статтею 4 Закону України «Про державну реєстрацію юридичних осіб, фізичних осіб підприємців та громадських формувань», тобто запису про припинення юридичної особи.

Отже, відповідно до цивільного законодавства при реорганізації (злитті) юридичних осіб перехід прав і обов 'язків до новоутвореної юридичної особи відбувається на підставі передавального акта, в якому про це має бути зазначено, а правонаступництво вважається здійсненим з моменту виключення юридичної особи попередника з Сдиного державного реєстру юридичних осіб, фізичних осі6 - підприємців та громадських формувань.

Оскільки немає завершення процесу припинення і відповідний запис до Сдиного державного реєстру юридичних осіб та фізичних осіб підприємців не внесено, то ДП «Донецька залізниця» залишається юридичною особою, яка продовжує самостійно нести відповідальність за договірними та позадоговір- 


\section{Цивільне, підприємницьке, господарське та трудове право}

ними зобов язаннями, що виникли за його участі".

При цьому варто пам'ятати про те, що спеціальним законодавством встановлюється спрощена процедура припинення деяких юридичних осіб. Відповідно до Закону України «Про спрощення процедур реорганізації та капіталізації банків" правонаступництво прав та обов’язків Банку, що приєднується, виникає у Банку-правонаступника з моменту, визначеного передавальним актом, затвердженим загальними зборами Банку, що приєднується, та Банку-правонаступника (Постанова Касаційного господарського суду від 07 лютого 2019 року Справа № 909/1411/13) [7].

ЦПК України не передбачено обов’язок суду здійснювати у відкритому провадженні моніторинг діяльності та правового статусу юридичних осіб, тому ризики недобросовісності учасників справи несуть сторони і треті особи. Розглянемо такі варіанти:

- юридична особа перебуває в процесі реорганізації, проте голова чи член комісії 3 реорганізації не бере участь у судовому розгляді (незалежно від мотивів). Колишній керівник чи член виконавчого органу втратили свої повноваження на представництво інтересів юридичної особи. Відповідач є належним, правонаступництво не виникло, адже формально юридична особа існує. В даному випадку має місце неявка відповідача у справі, який $є$ належно повідомленим про час та місце судового розгляду, без поважних причин неявки або не повідомлення про поважні причини, що тягне за собою розгляд справи без його участі;

якщо ж позивач не з'являється у судові засідання, то застосовуються аналогічні положення, за тим винятком, що у випадку повторної неявки як позивача, так і його договірного представника, суд залишає позовну заяву без розгляду;

- при реорганізації на етапі виконання судових рішень, голова комісії з реорганізації або їі член зобов'язані звернутись до суду з заявою про заміну сторони виконавчого провадження.

Уповноважені особи, які здійснюють діяльність, спрямовану на припинення юридичної особи, зобов'язані надати документи, які підтверджують їх повноваження на здій- снення процесуального самопредставництва (Ухвала Київського апеляційного суду у справi №№ 761/18524/19).

Повернемось до питання визначення моменту припинення юридичної особи шляхом реорганізації. Відповідно до ч. ч. 5-8 ст. 4 Закону України "Про державну реєстрацію юридичних осіб, фізичних осіб - підприємців та громадських формувань" злиття вважається завершеним 3 дати державної реєстрації припинення юридичних осіб, що припиняються у результаті злиття; перетворення вважається завершеним з дати державної реєстрації новоутвореної юридичної особи; поділ вважається завершеним 3 дати державної реєстрації припинення юридичної особи, що припиняється у результаті поділу; приєднання вважається завершеним 3 дати державної реєстрації змін до відомостей, що містяться в Сдиному державному реєстрі, щодо правонаступництва юридичної особи, до якої приєднуються.

Оскільки “новий” ЦПК України забороняє зупиняти провадження у справі у випадку реорганізації юридичної особи, суди постановляють ухвали про перерву у судовому засіданні для вчинення формальних дій, необхідних для виявлення, залучення у справу правонаступників, перевірки їх повноважень та вчинення інших процесуальних дій.

Так, ухвалою Гайсинського районного суду Вінницької області від 06 грудня 2019 р. суд залучив на підставі клопотання представника Особи 3 до участі в справі правонаступника позивача ОСОБА_4 ОСОБА_3. Цією ж ухвалою суд оголосив перерву в судовому засіданні до 10-00 години 12.02.2020 року для направлення правонаступнику позивача ОСОБА_3 цю ухвалу та судову повістку, роз'яснив що відповідно до ч. 2 ст. 55 ЦПК України всі дії, вчинені в цивільному процесі до вступу правонаступника, обов язкові для нього так само, як вони були обов `язкові для особи, яку він замінив.

Не вважаємо за доцільне запитувати сторін дозвіл на залучення правонаступника, оскільки не можна ототожнювати інститут процесуального правонаступництва 3 інститутом заміни неналежного відповідача належним, що здійснюється виключно за клопотанням позивача. У “новому” ЦПК України на 
забезпечення принципів диспозитивності та змагальності виключена можливість заміни неналежного позивача. 3 детального аналізу статті 55 ЦПК України ми дійшли висновку, що в ній імперативно встановлений обов'язок суду залучити правонаступника сторони або третьої особи за власною ініціативою чи за клопотанням учасника справи на будь-якій стадії судового процесу, якщо є безспірні докази, які підтверджують факт правонаступництва та особу правонаступника, незалежно від наявності чи відсутності заперечень з боку інших осіб та процесуального статусу учасника процесу.

За загальним правилом заміна кредитора у зобов'язанні здійснюється без згоди боржника. При цьому стаття 512 ЦК України розрізняє способи заміни кредитора, зокрема шляхом правонаступництва та укладенням договору про відступлення права вимоги. Боржник у зобов'язанні може бути замінений іншою особою (переведення боргу) лише за згодою кредитора, якщо інше не передбачено законом. Провівши комплексний аналіз норм щодо заміни сторони у зобов'язанні, приходимо до висновку, що вимоги статті 520 ЦК України поширюються на договірні відносини, які виникають на підставі укладення між попереднім та новим боржником договору про переведення боргу (який також за своєю природою може бути багатостороннім і включати як сторону кредитора).

Про це неодноразово в своїх постановах наголошував Верховний суд, як приклад наводимо рішення Касаційного цивільного суду від 25 квітня 2018 року, справа № 667/933/14ц: “як свідчить тлумачення статей 520, 521 ЦК України при заміні боржника первісний боржник вибуває із зобов' язання і замінюється новим боржником. Для породження переведенням боргу правових наслідків необхідним 6 існування двох складових: по-перше, вчинення двостороннього правочину між новим та первісним боржниками, причому такий правочин має вчинятися у такій самій формі, що і правочин, на підставі якого виникло зобов'язання; по-друге, надання кредитором згоди на переведення боргу”. Якщо ж кредитор дозволу на заміну боржника не надавав, то він має право на підставі статті 203
ЦКУ звернутись до суду про визнання такого договору недійсним.

Судова практика іде протилежним шляхом і в багатьох ухвалах можна знайти наступні формулювання: “відповідачі ОСОБА_1 та ОСОБА_2 в підготовчому засіданні не заперечували проти задоволення заявленого клопотання про залучення правонаступника позивача ”, - ухвала у справі № 381/3085/19.

”Від представник відповідача ОСОБА_1 адвоката ОСОБА_3 надійшла заява, згідно 3 якої не заперечує проти задоволення клопотання", - ухвала від 25 березня 2019 р., справа №346/4564/17.

“Заперечень від сторони позивача або правонаступника не надходило”, - ухвала від 24 грудня 2019 року, справа 727/10050/15.

Суд зобов'язаний зупинити провадження у справі у разі перебування сторони або третьої особи, яка заявляє самостійні вимоги щодо предмета спору, у складі Збройних сил України або інших утворених відповідно до закону військових формувань, що переведені на воєнний стан або залучені до проведення антитерористичної операції (зараз Операції об'єднаних сия).Отже, на відміну від попередньої редакції ЦПК України, процесуальний привілей у вигляді обов'язкового зупинення провадження за вищенаведеною підставою надано і третій особі, що заявляє самостійні вимоги щодо предмета спору. Крім того, законодавець поширив положення цієї норми на осіб залучених, до проведення антитерористичної операції (з 30 квітня 2018 року Операції об'єднаних сил)

До внесення змін у ЦПК України АТО тривала 3 роки, попередня редакція статті дозволяла, як власне і зараз, зупинення провадження у зв'язку з перебуванням сторони (або третьої особи, яка заявляє самостійні вимоги щодо предмета спору - на даний час), у складі Збройних сил України або інших утворених відповідно до закону військових формувань, що переведені на воєнний стан. Тобто якщо особа перебувала (є) у складі Збройних сил чи інших військових формувань (військова служба за призовом під час мобілізації, на особливий період; військова служба за контрактом осіб рядового складу; військова служба за контрактом осіб сержантського і старшинського складу, інші види 


\section{Цивільне, підприсмницьке, господарське та трудове право}

виконання військового обов'язку, крім перебування учасника справи на альтернативній (невійськовій) службі не за місцем проживання або на строковій військовій службі, оскільки в таких випадках зупинення провадження є правом суду), то формально судді зупинити провадження не могли і не можуть, якщо не введений указом Президента України воєнний стан в Україні або в окремих їі місцевостях. Багато суддів на власний страх та ризик скасування їх рішення судами вищестоящих інстанцій постановляли(ють) ухвали про зупинення провадження на цій підставі (ухвала Апеляційного суду Вінницької області від 03 березня 2017 року, справа № 149/2428/16ц, постанова Апеляційного суду Запорізької області від 18 травня 2018 року, справа 206/7711/14-ц).

Непоодинокими були випадки, коли судді, керуючись принципами верховенства права та справедливості, спрямованості діяльності суду на захист прав та інтересів учасників справи відходили від встановленого ЦПК України імперативного правила та підтримували рішення нижчестоящих судів, а також заповнювали прогалини у законодавчому регулюванні. Адже до грудня 2017 року судам нічого не залишалось, як застосововувати аналогію закону при вирішенні питання про зупинення провадження у зв'язку з участю в АТО на підставі п. 3.ст 201 попередньої редакції ЦПК України.

Показовою є справа № 453/1311/15, у якій апеляційний суд залишив у силі ухвалу Сколівського районного суду Аьвівської області про зупинення провадження у зв'язку з участю відповідача в АТО і вказав: "Відповідно до довідок №1429 від 29.09.2015 року, №1927 від 15 грудня 2015 року, №1929 від 15 грудня 2015 року, виданих Військовою частиною польової пошти В2803 лейтенант ОСОБА_4 дійсно з 24 вересня 2015 року по 28 листопада 2015 року, 311 грудня 2015 року і на час видачі довідки від 15.12.2015 року безпосередньо бере участь в антитерористичній операції, забезпеченні їі проведення і захисті незалежності, суверенітету та територіальній цілісності України в районі проведення антитерористичній операції на території Донецької та Ауганської областей.
Враховуючи такі дані, відповідач у справі не має об’єктивної можливості взяти участь у розгляді справи, чого бажає, з обставин, визначених у п. 3 ч. I ст. 201 ЦПК України.

За таких обставин у суду були правові підстави для вирішення питання про зупинення провадження у справі незалежно від відсутності на даний час відповідного Указу Президента України щодо введення воєнного стану на території України чи в окремих іiі областях".

Неузгодженість норм процесуального та матеріального права, невідповідність їх реальному стану речей змушує суди шукати шляхи вирішення ключових проблем, застосовуючи загальні принципи права, аналогію та мораль, навіть якщо вони не повністю відповідають букві процесуального закону.

Завдяки внесеним у 2017 році змінам суди отримали можливість зупиняти провадження у справі у зв'язку із залученням осіб до проведення антитерористичної операції, незалежно від того, чи введено указом Президента України воєнний стан, чого не скажеш, на жаль, про зупинення провадження у зв'язку з перебуванням сторони або третьої особи, яка заявляє самостійні вимоги щодо предмета спору, у складі Збройних Сил України або інших утворених відповідно до закону військових формуваннях.

Відповідно до п.1.ч.1.ст 8 Закону України “Про особливості державної політики із забезпечення державного суверенітету України на тимчасово окупованих територіях у Донецькій та Ауганській областях" від 18.01.2018 року, Генеральним штабом Збройних Сил України за погодженням з відповідними керівниками залучаються та використовуються сили і засоби (особовий склад та спеціалісти окремих підрозділів, військових частин, зброя, бойова техніка, спеціальні і транспортні засоби, засоби зв'язку та телекомунікацій, інші матеріально-технічні засоби) Збройних Сил України, інших утворених відповідно до законів України військових формувань (Служби безпеки України, Державної служби спеціального зв'язку та захисту інформації України, Національної гвардії України, Державної прикордонної служби України, Управління державної охорони України, Державної спеціальної служби транспорту), 
правоохоронних органів спеціального призначення, Міністерства внутрішніх справ України, Національної поліції України, розвідувальних органів України, військової прокуратури, центрального органу виконавчої влади, що реалізує державну політику у сфері цивільного захисту, а також працівники закладів охорони здоров'я [6].

Згідно з Наказом Верховного Головнокомандувача ЗСУ "Про початок операції Об'єднаних сил із забезпечення національної безпеки і оборони, відсічі та стримування збройної агресії Російської Федерації на території Донецької та Ауганської областей», о 14.0030 квітня 2018 року розпочалась операція Об'єднаних сил із забезпечення національної безпеки і оборони, відсічі та стримування збройної агресії Російської федерації у Донецькій і Луганській областях, відповідно до плану операції Об’єднаних сил. Особи, які залучаються до проведення антитерористичної операції, стали особами, які залучаються до здійснення заходів із забезпечення національної безпеки і оборони, відсічі і стримування збройної агресії Російської Федерації безпосередньо у Донецькій та Ауганській областях

Чи можемо ми говорити про відмову у зупиненні провадження у зв'язку з тим, що законодавець досі не вніс зміни в ЦПК України? Однозначно ні.

Наступна підстава, яку ми хочемо проаналізувати, 6 новою для українського цивільного процесу. На сьогодні судді обов'язково зупиняють провадження у зв'язку з врегулюванням спору за участю судді. Так звана судова медіація, яка широко застосовується в різних країнах, потроху вливається в українське життя.

На нашу думку, врегулювання спору за участю судді представляє собою сукупність процесуальних дій суду та сторін (іх представників), які вчиняются до початку розгляду справи по суті, шляхом проведення спільних та (або) закритих нарад в умовах конфіденційності, з метою швидкого та мирного врегулювання спору між сторонами.

Проведення врегулювання спору за участю судді не допускається у разі, якщо у справу вступила третя особа, яка заявляє самостійні вимоги щодо предмета спору.
Про проведення процедури врегулювання спору за участю судді суд постановляє ухвалу, якою одночасно зупиняє провадження у справі.

Врегулювання спору за участю судді проводиться протягом розумного строку, але не більше тридцяти днів 3 дня постановлення ухвали про його проведення. Строк проведення врегулювання спору за участю судді продовженню не підлягає.

Стаття 204 ЦПК України визначає момент припинення врегулювання спору за участю судді. Про припинення врегулювання спору за участю судді постановляється ухвала, яка оскарженню не підлягає. Одночасно суддя вирішує питання про поновлення провадження у справі.

Складністю врегулювання спору за участю судді є новизна цього інституту. Суддям під час проведення переговорів зі сторонами, особливо в тих випадках, коли відсутні адвокати, потрібно застосовувати не тільки юридичні знання і навички, але і здібності хорошого психолога- медіатора.

Суд зобов'язаний зупинити провадження у справі у разі об'єктивної неможливості розгляду цієї справи до вирішення іншої справи, що розглядається в порядку конституційного провадження, адміністративного, цивільного, господарського чи кримінального судочинства, - до набрання законної сили судовим рішенням в іншій справі; суд не може посихатися на об'єктивну неможливість розгляду справи у випадку, коли зібрані докази дозволяють встановити та оцінити обставини (Факти), які є предметом судового розгляду.

Зміст п. 6. ч.1 ст. 251 ЦПК України очевидно був розширений 3 метою своєчасного та об'єктивного розгляду справи судом, запобігання необгрунтованого затягування іiі розгляду, зловживання процесуальними права учасниками процесу.

Визначаючи наявність підстав, за яких провадження у справі підлягає обов'язковому зупиненню, суд повинен, зокрема, враховувати, що така підстава для зупинення провадження у справі застосовується у тому разі, коли в іншій справі можуть бути вирішені питання, що стосуються підстав, заявлених у справі вимог, чи умов, від яких залежить можливість іï розгляду (Ухвала Касаційно- 


\section{Цивільне, підприємницьке, господарське та трудове право}

го цивільного суду від 06 травня 2019 року у справі № 314/1787/17).

Відповідні норми спрямовані, зокрема, на попередження ухвалення судових рішень, виходячи $з$ доказів і встановлених на їх підставі обставин, які можуть бути спростованими рішенням у іншій справі, що розглядається в порядку конституційного, цивільного, господарського, кримінального чи адміністративного судочинства (Постанова Касаційного цивільного суду від 14 березня 2019 року у справі № 308/1 1448/14-ц).

Пов'язаною $з$ даною справою є така інша справа, у якій інший суд встановлює обставини, що впливають чи можуть вплинути на подання і оцінку доказів у цій справі; у тому числі йдеться про факти, які мають преюдиційне значення.

Під неможливістю розгляду даної справи слід розуміти неможливість для суду самостійно встановити обставини, які встановлюються іншим судом в іншій справі, - у зв'язку 3 непідвідомчістю або непідсудністю іншої справи даному суду, одночасністю розгляду двох пов'язаних між собою справ різними судами або з інших причин.

Для вирішення питання про зупинення провадження у справі суду слід у кожному випадку з'ясовувати: як саме справа, що розглядається судом, пов'язана зі справою, яка розглядається іншим судом, чим саме обумовлюється неможливість розгляду справи (Ухвала Касаційного цивільного суду від 10 січня 2019 року у справі № 361/1028/18).

Підставою зупинення провадження у справі не може бути касаційне оскарження попередніх судових рішень у справі, оскільки ці рішення вже набрали законної сили (Постанова Касаційного цивільного суду від 17 квітня 2019 року у справі № 752/1914/16-ц).

Суд на дотримання вимог пункту 6 частини першої статті 251 ЦПК України, зазначивши конкретну іншу справу, до вирішення якої зупиняється провадження у справі, повинен проаналізувати предмети спорів у справах і вказати обставини, які б давали підстави для висновку про те, що наявність спору у справі виключає можливість на підставі наявних доказів самостійно встановити при розгляді даної справи наявність обставин, якими сторона обгрунтовувала свої вимоги, причинний матеріально-правовий зв'язок, який виражається у тому, що факти, встановлені в одній із справ, будуть мати преюдиційне значення для іншої справи (Постанова Касаційного цивільного суду від 27 лютого 2019 року у справі № 308/5006/16-ц).

\section{Висновок}

Дії уповноважених осіб, які спрямовані на припинення юридичної особи та їі остаточна реорганізація з передачею прав та обов'язків правонаступникам, $є$ різними правовими категоріями та тягнуть за собою відмінні процесуальні наслідки. Вважаємо за необхідне змінити положення про зупинення провадження у зв'язку з перебуванням сторони або третьої особи, яка заявляє самостійні вимоги щодо предмета спору, у складі Збройних сил України або інших утворених відповідно до закону військових формувань, тільки за умови введення воєнного стану, слова "залучені до антитерористичної операції” варто доповнити "або до здійснення заходів із забезпечення національної безпеки і оборони, відсічі і стримування збройної агресії Російської Федерації в Донецькій та Ауганській областях". Ці нововведення сприятимуть виробленню єдиної судової практики, гарантуватимуть додержання прав учасників процесу та відповідатимуть реаліям життя.

\section{Література}

1. Господарський процесуальний кодекс України від 06.11.1991 № 1798-XII V [Електронний ресурс] - Режим доступу: https:// zakon.rada.gov.ua/laws/show/1798-12

2. Кодекс адміністративного судочинства України від 06.07.2005 № 2747-IV [Електронний ресурс] - Режим доступу: https:// zakon.rada.gov.ua/laws/show/2747-15

3. Цивільний кодекс України від 16.01.2003 № 435-IV [Електронний ресурс] Режим доступу: https://zakon.rada.gov.ua/laws/ show/435-15

4. Цивільний процесуальний кодекс України від 18.03.2004 № 1618-IV [Електронний ресурс] - Режим доступу: https://zakon. rada.gov.ua/laws/show/1618-15

5. Закон України "Про внесення змін до Господарського процесуального кодексу України, Цивільного процесуального кодексу 
АНОТАЦІЯ
у статті $\quad$ досліджуються підстави обов'язкового зупинення провадження у справi, практика застосування судами статті 251 Цивільного процесуального кодексу Украӥни. Визначається важливість изього інституту як процесуальної гарантї забезпечення прав та свобод учасників процесу, в той же час нерідко зупинення провадження використовується недобросовісними особами для затягування розгляду справи судом, що має наслідком порушення принщипу розумності строків розгляду справи судом та свідчить про зловживання процесуальним правами. На недопущення ичх негативних явищ були спрямовані внесені у 2017 році зміни до Цивільного процесуального кодексу Украӥни.

Особлива увага приділяється порядку залучення процесуального правонаступника припиненої юридичної особи, надається визначення поняття “врегулювання спору за участю судді", у статті містяться посилання на позииї Верховного суду, висвітлюються основні проблеми, з якими зіштовхуються судді, застосовуючи досліджувані у статті правові норми. Авторами пропонуються шляхи удосконалення норм щодо визначення підстав обов'язкового зупинення провадження судом.

Ключові слова: зупинення провадження, процесуальне правонаступництво, Антитерористична операиія, Операиія об'єднаних сил, врегулювання спору за участю суддi, преюдиція.

України, Кодексу адміністративного судочинства України та інших законодавчих актів" від 03.10.2017 № 2147-VIII [Електронний ресурс] - Режим доступу: https://zakon.rada.gov. $\underline{\text { ua/laws/show/2147-19 }}$

6. Закон України "Про особливості державної політики із забезпечення державного суверенітету України на тимчасово окупованих територіях у Донецькій та Ауганській областях" від 18.01.2018 № 2268-VIII [Електронний ресурс] - Режим доступу: https://zakon. rada.gov.ua/laws/show/2268-19

7. Закон України «Про спрощення процедур реорганізації та капіталізації банків”від 23.03.2017 № 1985-VIII [Електронний ресурс] - Режим доступу: https://zakon.rada.gov.ua/ laws/show/1985-19

\section{SUMMARY}

The article explores grounds for obligatory suspension of proceedings, the practice of court's application of the Article 251 of the Civil Procedure Code of Ukraine. The importance of this institute is determined as a procedural guarantee of ensuring the rights and freedoms of the participants of the process. At the same time, often the suspension of the proceedings is used by unscrupulous persons to delay the hearing of the case by a court, which results in violation of the principle of reasonable time of the court hearing and indicates abuse of procedural rights. In 2017, amendments to the Civil Procedure Code of Ukraine were aimed at preventing these negative phenomena.

Particular attention is paid to the procedure Of involving a legal successor of a terminated legal person. The process of termination of a legal person is long-lasting, until the relevant information is entered in the Unified State Register of legal persons, natural persons - entrepreneurs and public organizations, the representation of its interests in court is carried out by competent persons. After entering the information on the termination of the legal person in the register, the court involves its successors in the case.

Courts should suspend proceedings if a party or a third party that claims independent demands relative to the subject of the dispute is involved in an Anti-terrorist Operation. But in 2018 Antiterrorist operation was replaced by Joint Forces Operation and names of the persons involved in Anti-terrorist Operation were changed too. So it is necessary to make changes to paragraph 2 of the first part of the Article 251 of the Civil Procedure Code of Ukraine. Also, we consider it necessary to amend the provisions on suspension of proceedings in connection with the stay of the party or the third party that claims independent demands relative to the subject of the dispute in the Armed Forces of Ukraine or other established under the law military units, only if martial law is introduced.

We gave the definition of "dispute resolution involving a judge" and main Supreme court s position, including decisions made on the basis of application of paragraph 6 of the first part of Article 251 of the Civil Procedure Code of Ukraine.

Key words: suspension of proceedings, procedural succession, Anti-terrorist Operation, Joint Forces Operation, dispute resolution involving a judge, prejudice. 